\title{
Production of Biodiesel from Mixed Waste Cooking and Castor Oil
}

\author{
Hadiyanto Hadiyanto ${ }^{1,2,3^{*}}$, Inaya Yuliandaru $^{1}$, and Rafidha Hapsari ${ }^{1}$ \\ ${ }^{1}$ Chemical Engineering Department, Faculty of Engineering, Universiats Diponegoro \\ ${ }^{2}$ Master program of Environmental Sciences, School of Postgraduate Studies, Universitas Diponegoro \\ ${ }^{3}$ Center of Biomass and Renewable Energy(CBIORE), Universitas Diponegoro
}

\begin{abstract}
Due to increasing population growth, the consumption and needs of energy increase significantly. This leads Indonesia government to search alternative energy to cover the lacks of fossil energy reserves. Biodiesel is one of the prospective alternative energy which are renewable and environmental friendly. A common problem in large-scale biodiesel production is the sustainability of feedstock and the biodiesel stability. Therefore, the purpose of this study was to evaluate the production of biodiesel from two oil sources i.e. waste cooking oil and castor oil. This study examined the effect of mixed oil ratio on yield, biodiesel characteristics and stability. The physical properties included kinematic viscosity, acid number, saponification number, iodine number and cetane number have been evaluated as function of oil ratio. Yield of biodiesel was obtained at 35.07\%, $99.2 \%$ and $83.69 \%$ for jatropha:castor oil ratio of 1: $0,1: 2$ and 2:1, respectively. Most of these characteristics showed an increase by increasing the oil ratio. The result concluded that at the ratio of $1: 1(\mathrm{v} / \mathrm{v})$ was the best characteristic and stability.
\end{abstract}

\section{Introduction}

Indonesia is the fourth most populous country in the world after China, India, the United States with a population of $237,641,326$ people [1]. The growth of the Indonesian population from the period of 2000-2010 averaged $1.49 \%$ per year, this gives a broad impact on energy needs. Energy consumption is still dominated by fuel oil (gasoline, diesel oil, kerosene, aviation fuel and avgas) [2]. Indonesia's oil reserves currently range from 4 billion barrels with an average oil production of 1 million barrels per day, while the demand for fuel oil reaches 1.2 million barrels per day so that the remainder of Indonesia's fuel needs is still imported. Due to this, the government is trying to develop alternative energy in preparation for the fuel oil crisis. One form of effort that has been done by the government is the utilization of biofuel or biodiesel [2].

Biodiesel is a mono-alkyl ester of a long chain of fatty acids having a carbon chain between 6-24 depending on the base material [3]. The presence of oxygen in biodiesel distinguishes it from petroleum diesel whose main component consists only of hydrocarbons. Biodiesel has chemical and physical properties similar to diesel therefore it can be used directly for diesel engines mixed with diesel [4].

Although the use of biodiesel benefits in many ways, which relies solely on single feedstocks, it also raises several problems like competition for food needs and the need for extensive land for the life cycle of biodiesel production [3]. Biodiesel production in Indonesia which still relies on palm oil affects the loss of biodiversity due to deforestation to meet the demand for palm oil.
Multi-feedstock biodiesel can reduce the dependence of biodiesel production on one type of raw material only. Based on research conducted by Elma et al., [5] the production of multi-feedstock and single feedstock biodiesels from coconut oil and cooking oil, the multifeedstock biodiesel was producing bigger conversion compared with the single feedstock biodiesel.

In the process of making biodiesel, an esterification and / or transesterification stage will be performed. The esterification reaction is a reaction between the carboxylic acid and the alcohol forming the ester. The carboxylic acid derivative forms a carboxylic acid ester. The carboxylic acid ester is a compound containing the COOR group with $\mathrm{R}$ may be either alkyl or aryl. Esterification of acid catalysed and reversible [6]. The esterification reaction converts the free fatty acids contained in the triglycerides into methyl esters. Meanwhile, transesterification is the reaction of an alcohol group exchange of an ester with another ester. The addition of an alkaline catalyst will accelerate the transesterification reaction in the formation of the ester [8]. Alcohols that can be used in the transesterification process of triglycerides are methanol, ethanol, propanol, butanol, and amyl alcohol.

In this research, multi-feedstock biodiesel will be produced, two kinds of oil will be varied composition as base materials. The materials are waste cooking oil and castor oil. The oil mixture will be processed into biodiesel through esterification and transesterification. This research will be focused on the production of multi feedstock biodiesel and biodiesel's stability analysis in order to know the composition of the mixture which able

Corresponding author: hadiyanto@live.undip.ac.id 
to produce biodiesel with a large yield, meet the standards and have the best stability.

\section{Materials and Method}

\subsection{Materials}

Waste cooking oil from Warung Burjo around Tembalang and Castor Oil from Chemical Shop Indrasari, Semarang. $\mathrm{KOH}, \mathrm{NaOH}, \mathrm{H} 2 \mathrm{SO} 4$, methanol, distilled water, ethanol 95\%, indicator pp, $\mathrm{HCl} 0,5 \mathrm{~N}$, $\mathrm{Na} 2 \mathrm{SO} 3$, Chloroform, Wijs solution, $\mathrm{CH} 3 \mathrm{COOH}$ were obtained from Chemical Store in Semarang.

\subsection{Raw Materials Pre-Analysis}

Preliminary analysis was performed to determine the initial FFA and molecular weight of the oil. If FFA $<2.5 \%$ esterification was not necessary.

\subsection{Esterification}

The transesterification process was carried out on a three-neck flask at $60^{\circ} \mathrm{C}$ with an agitation of $400 \mathrm{rpm}$. The oil mixture at the top of the funnel separator was introduced into the third neck flask and then $\mathrm{KOH}$ mixed with methanol corresponding to the ratio was inserted and reacted for $90 \mathrm{~min}$.

\subsection{Purification}

Purification was performed 2 stages; first stage is separation by separating funnel. Two layers would be formed and separated, the top layer, a mixture of oil, methanol and methyl esters, was further purified. The bottom layer which is a glycerol was not needed. The second stage was washing by adding $20 \mathrm{~mL}$ water $60^{\circ} \mathrm{C}$ on the top layer in separating funnel, wait for one minute until two layers formed. The washing stage would be done until the washing water is clean.

\subsection{Analysis}

The biodiesel synthesis results were qualitatively identified using Gas Chromatography Mass Spectrometry (GCMS) and quantitative analyzed by titration method i.e. kinematic viscosity at $40^{\circ} \mathrm{C}$, acid number, saponification number, iodine number, and cetane number. This analysis was conducted each week during experiment.

\section{Results and Discussion}

\subsection{Effect of oil ratio to biodiesel yield}

From Figure 1 it is shown that the yield of single feedstock of waste cooking oil was very low, about $35.07 \%$ as obtained from GCMS analysis. Low yield may be caused by oleic acid content of waste cooking oil. Oleic acid is susceptible to oxidation reactions because it has a low activation energy [9]. The presence of oxidation reactions will reduce the fatty acids that should turn into methyl esters. In contrast, the castor oil contains risinoleic acid which is not easily oxidized. Therefore, a mixture of waste cooking oil and castor oil can produce higher yield biodiesel. The test results showed biodiesel yield with 1:2 oil volume ratios of $99.20 \%$ and $2: 1$ (vol/vol) of $83.69 \%$.

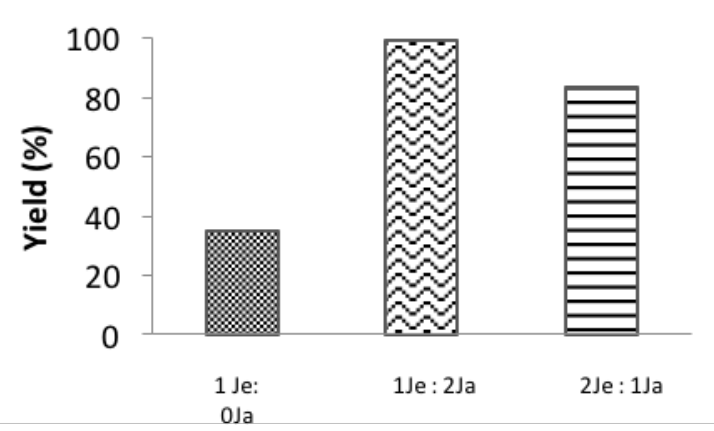

Fig. 1. Yield of biodiesel with variation of ratio of waste cooking oil (Je): castor oil (Ja) (v/v)

\subsection{Effect of oil ratio to biodiesel properties}

The increase of oil ratio will affect to decrease biodiesel kinematic viscosity at $40^{\circ} \mathrm{C}$ (Fig 2). Biodiesel produced by castor oil has a high viscosity because its content is dominated by risinoleic acid. The high content of risinoleic acid will provide higher viscosity [10]. Mixing of oil will affect the composition of the fatty acids contained in the oil. Since waste cooking oil is dominated by oleic acid which results in lower viscosity, mixing of waste cooking oil with castor oil can produce biodiesel with lower viscosities. In addition, high viscosity can also be caused by the presence of fatty acids in the product and does not turn into methyl esters[11].

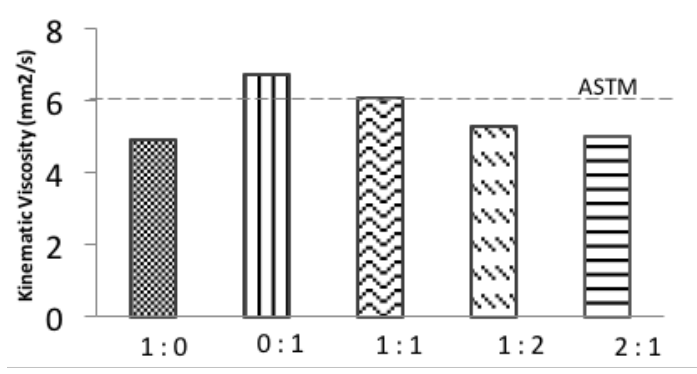

Fig. 2. Kinematic viscosity of biodiesel at various oil ratio (Je : Ja) 
Figure 3 shows that biodiesel from waste cooking oil has the largest saponification number. This is due to the dominant oleic acid in waste cooking oil has shorter carbon chains than the dominant fatty acids in castor oil which causes smaller molecular weights. Smaller molecular weights will yield relatively larger saponification number. In waste cooking oil mixed with castor oil, it is found that the saponification number became lower. Castor oil contains the dominant fatty acids in the form of ricinoleic acid which have longer carbon chain. So that the molecular weight is relatively larger which causes the saponification value tends to be lower.

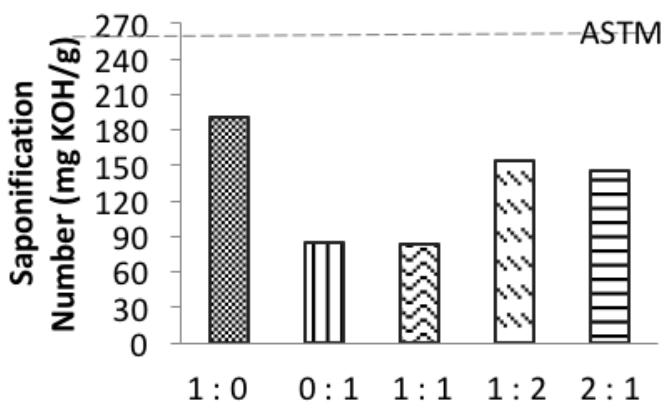

Fig. 3. Saponification number of biodiesel at various oil ratio (Je:Ja)

Based on Fig 4 it is shown that the variables which have higher castor oil ratio resulted higher acid number than the waste cooking oil. High acid numbers can be caused by the oxidation process. Contact with air can also cause oxidation because oxygen can lead aggressive biodiesel reaction and produce degradation compounds such as acids, aldehydes, ketones, dissolved compounds[12]. Acid can be formed because of the water content in biodiesel causing the hydrolysis reaction that converts the ester into alcohol [13].

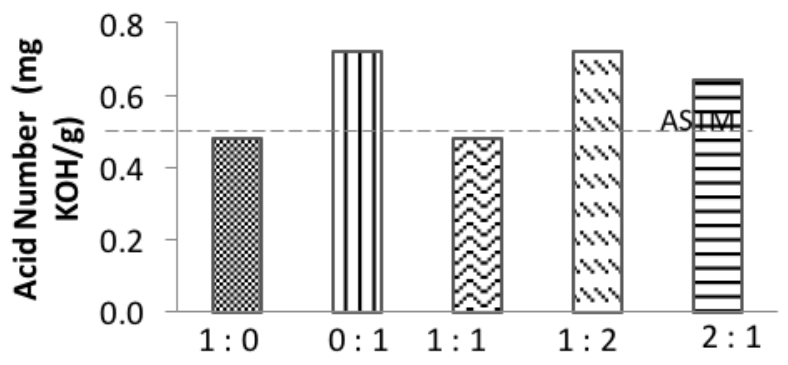

Fig. 4. Acid number of biodiesel at various oil ratio (Je:Ja)

The iodine number is strongly influenced by the double bonds in the dominant fatty acids in the oil. Cooking oil and castor oil composition are predominantly unsaturated fatty acids (double bonded). This leads the mixing of both oils will increases the iodine number (Fig 5). In biodiesel, high iodine is less desirable because biodiesel with high iodine tends to be polymerized so that it is less stable [14].

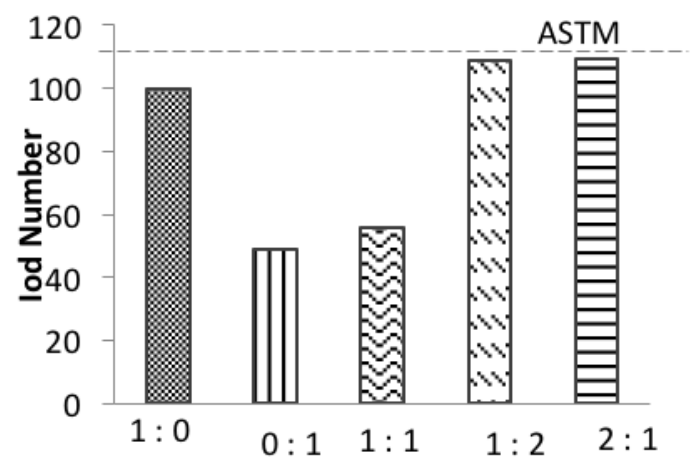

Fig. 5. Iod Number of biodiesel at various oil ratio (Je:Ja)

Cetane numbers are strongly influenced by the chemical structure of fatty acids that composed the biodiesel(Fig 6). The more double bonds and the shorter the carbon chain will decrease the cetane number [15]. Mixing oil produces biodiesel with a higher cetane number. The addition of castor oil that has a fatty acid with fewer double bonds and a longer carbon chain will result in larger cetane numbers.

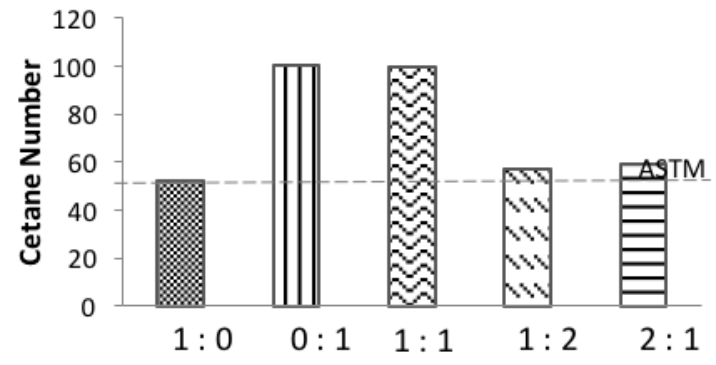

Fig. 6. Cetane number of biodiesel at various oil ratio (Je:Ja)

\section{Conclusion}

Biodiesel with the highest yield was obtained with the ratio of volume of cooking oil to castor oil at 1: 2 with yield of $99.20 \%$. The characteristics of biodiesel are greatly influenced by the fatty acid content contained in the oil of the manufacture raw material. Mixing of the oils increased or decreased the biodiesel characteristics such as viscosity, density, saponification, and cetane number. Mixing of raw materials did not result in a stable biodiesel than mixture of oil feedstock. The 1Je: $1 \mathrm{Ja}$ composition is ratio that gave the best result in terms of biodiesel physical characteristic and the product almost meet the standard. 


\section{References}

1. BPS (Badan Pusat Statistik). https://bps.go.id/website/pdf_publikasi/DistribusiPerdagangan-Komoditas-Minyak-Goreng-di-Indonesia2016.pdf. Accessed on 1 Juli 2016

2. A. Sugiyono, L. Anindhita, M.A. Wahid \& Adiarso.(ed), Outlook Energi Indonesia 2016 (Pusat Teknologi Sumber Daya Energi dan Industri Kimia, Jakarta, 2016)

3. M.I. Jahirul, R.J.Brown, W.Senadeera, I.M. O'Hara, Z.D.Ristovski. Energies. 6, 3764-3806 (2013)

4. P. Verma and M.P. Sharma. Renewable and Sustainable Energy Reviews. 62, 1063-1071 (2016).

5. M.Elma, S.A. Suhendra and W.Wahyuddin. Konversi. 5 (1) (2016)

6. R.J. Fessenden, J.S.Fessenden, and M.W.Logue, Organic Chemistry (2nd edition). Brooks Cole Publishing Company (1982).

7. J. Pullen and S. Khizar. Renewable and Sustainable Energy Reviews 16 5924-5950 (2012).

8. Istadi, Teknologi Katalis untuk Konversi Energi; Fundamental dan Aplikasi (1sted.) (Graha Ilmu, Yogyakarta, 2011)

9. D. Desnelli and Z. Fanani. Jurnal Penelitian Sains 12, 1(C) (2009)

10. A.Amin, A. Gadallah, A.K. El Morsi, N.N. El-Ibiari, G.I. El-Diwani. 2016. Egyptian Journal of Petroleum. 25 (4), 509-5014 (2016).

11. T.Kusumaningsih, P.Pranoto and R. Saryoso. Bioteknologi 3(1), 20-26 (2006).

12. S.Silviana and L.Buchori. Reaktor, 15(3), 148-153 (2015)

13. A. Bouaid, M. Martinez, J. Aracil. Fuel, 86, 2596-2602 (2007)

14. L. Adhani, A. Isalmi, S. Nurbayati and C. O. Okatviana. Jurnal Penelitian dan Pengembangan Ilmu Kimia, 2(1), 71-80 (2016).

15. M. Angelovic, Z. Tkac and J. Jablonicky. Animal Science and Biotechnologies, 47 (1), 2014 